\title{
172. Effect of Sodium Chloride on Alkaline Phosphatase Activity in Intestinal Mucosa of the Rainbow Trout
}

\author{
By Seiitiro UTIDA \\ Ocean Research Institute, University of Tokyo \\ (Comm. by Yô K. OKaDA, M.J.A., Oct. 12, 1967)
}

It is well known that mammalian alkaline phosphatase is a zinc protein and activated with a low concentration of divalent cations, especially $\mathrm{Mg}^{++} .{ }^{1)}$ On the other hand, monovalent cations, such as $\mathrm{Na}^{+}$and $\mathrm{K}^{+}$at high concentrations have been reported to accelerated the activity of alkaline phosphatase in both halophilic ${ }^{2)}$ and nonhalophilic ${ }^{3)}$ bacteria.

The present paper deals with the effect of $\mathrm{NaCl}$ and $\mathrm{MgSO}_{4}$ on the alkaline phosphatase activity in intestinal mucosa of the rainbow trout, and also the effect of sea-water adaptation of rainbow trout on their intestinal alkaline phosphatase activity.

Materials and methods. The two-year-old rainbow trout, Salmo gairdnerii irideus was purchased from a commercial fishpond. These fish, weighing from 70 to $100 \mathrm{~g}$ were kept in a separate tank containing about 15 liter of aerated and dechlorinated tap water at $14 \pm 1^{\circ} \mathrm{C}$ for at least 10 days before use. Adaptation of the rainbow trout to artificial sea water was carried out stepwise; they were suceedingly transferred into 50,75, and $100 \%$ sea water for respective two days. The artificial sea water contained $462 \mathrm{mM} \mathrm{NaCl}, 9.4 \mathrm{mM} \mathrm{KCl}$, $10.8 \mathrm{mM} \mathrm{CaCl}_{2}, 24 \mathrm{mM} \mathrm{MgCl}_{2}$, and $6 \mathrm{mM} \mathrm{NaHCO}_{3}(\mathrm{pH} \mathrm{8.0})$.

For preparation of the enzyme solution, the trout was killed by decapitation, and the intestine was removed quickly and opened. After washing with Ringer solution and blotting with filter paper, the intestinal mucosa was scraped, weighed and homogenized with 20 volumes of ice-cold $0.25 \mathrm{M}$ sucrose solution. In a few cases, deionized water was used as homogenizing medium. The homogenate was centrifuged at $1,000 \times g$ for 10 minutes and the supernatant was recentrifuged at $20,000 \times g$ for 30 minutes. Usually, the resulting precipitates were suspended in deionized water and used as enzyme preparation.

Alkaline phosphatase activity was measured by using p-nitrophenylphosphate disodium as substrate. The final volume of the reaction mixture was $2.0 \mathrm{ml}$, containing $2 \mathrm{mM}$ substrate, $100 \mathrm{mM}$ ethanolamine-HCl buffer ( $\mathrm{pH} 9.5), 0.2 \mathrm{ml}$ enzyme solution $(5-10 \mathrm{mg}$ 
original wet weight) and with or without $\mathrm{NaCl}$ and $\mathrm{MgSO}_{4}$. The mixture was incubated at $25^{\circ} \mathrm{C}$ for 10 minutes and the reaction was stopped by addition of $1.0 \mathrm{ml}$ of $20 \%$ trichloroacetic acid. After centrifugation, three volumes of $0.5 \mathrm{~N} \mathrm{NaOH}$ were added to an aliquot of the supernatant solution and the resulting $p$-nitrophenol was estimated with a photometer at $420 \mathrm{~m} \mu$. In the presence of magnesium ions, the inorganic phosphate liberated instead of $p$ nitrophenol was estimated by the method of Lohmann and Jendrássik. ${ }^{4)}$ The enzyme activity was expressed as $\mu$ moles $p$-nitrophenol ( $p$-NP) or inorganic phosphate $(\mathrm{P} i)$ liberated per $\mathrm{g}$ original tissue per minute.

Results. Effect of $\mathrm{NaCl}$ and $\mathrm{MgSO}_{4}$. A high concentration of $\mathrm{NaCl}$ was found to enhance the alkaline phosphatase activity in the homogenate of intestinal mucosa of the rainbow trout; $2.30 \mu$ moles $p-\mathrm{NP} / \mathrm{g} / \mathrm{min}$ in the absence of $\mathrm{NaCl}$ and $3.18 \mu$ moles $p-\mathrm{NP} / \mathrm{g} / \mathrm{min}$ in the presence of $500 \mathrm{mM} \mathrm{NaCl}$. Next, the activity of alkaline phosphatase in various subcellular fractions obtained by differential centrifugation of the mucosal homogenate was estimated in the presence or absence of $\mathrm{NaCl}$. When the mucosal tissue was homogenized in $0.25 \mathrm{M}$ sucrose solution, the highest activity was found in the precipitate after centrifugation at $20,000 \times g$. The marked activation by $500 \mathrm{mM} \mathrm{NaCl}$ was also observed in the same fraction although some activation by $\mathrm{NaCl}$ was seen in the precipitate after $1,000 \times g$ and the supernatant after $20,000 \times g$. When the tissue was homogenized in deionized water, no activation was found in the supernatant after centrifugation at $20,000 \times g$. It is to be noted that although the distribution of the phosphatase activity was slightly different between fractionations by sucrose and water, the total enzyme activity was completely identical. A typical example of these results is shown in Table I.

Table I. Alkaline phosphatase activity in subcellular fractions of intestinal mucosa with or without $500 \mathrm{mM} \mathrm{NaCl}$

\begin{tabular}{c|ccc|ccc}
\hline & \multicolumn{3}{|c|}{ Sucrose } & \multicolumn{3}{c}{ Deionized water } \\
\cline { 2 - 4 } \cline { 5 - 6 } & $\mathrm{NaCl}(-)$ & $\mathrm{NaCl}(+)$ & Ratio (+/-) & $\mathrm{NaCl}(-)$ & $\mathrm{NaCl}(+)$ & Ratio (+/-) \\
\cline { 3 - 6 } $\mathrm{P}-1,000$ & $\left.0.36^{*}\right)$ & 0.42 & 1.16 & 0.24 & 0.28 & 1.17 \\
$\mathrm{P}-20,000$ & 0.63 & 0.91 & 1.46 & 0.92 & 1.29 & 1.40 \\
$\mathrm{~S}-20,000$ & 0.39 & 0.45 & 1.14 & 0.21 & 0.21 & 1.00 \\
Total & 1.38 & 1.78 & & 1.37 & 1.78 & \\
\hline
\end{tabular}

*) $\mu$ moles $p-\mathrm{NP} / \mathrm{g} / \mathrm{min}$.

The effect of $\mathrm{NaCl}(500 \mathrm{mM})$ and $\mathrm{MgSO}_{4}(5 \mathrm{mM})$ on the phosphatase activity in both fractions of the precipitate $(\mathrm{P}-20,000)$ and the supernatant (S-20,000) derived from deionized water homogenates 
Table II. Effect of $500 \mathrm{mM} \mathrm{NaCl}$ and $5 \mathrm{mM} \mathrm{MgSO}_{4}$ on alkaline phosphatase activity

\begin{tabular}{c|c|cc|cc|cc}
\hline & $\begin{array}{c}\text { None } \\
(-)\end{array}$ & $\begin{array}{c}\mathrm{NaCl} \\
(+)\end{array}$ & $\begin{array}{c}\text { Ratio } \\
(+/-)\end{array}$ & $\begin{array}{c}\mathrm{MgSO}_{4} \\
(+)\end{array}$ & $\begin{array}{c}\text { Ratio } \\
(+/-)\end{array}$ & $\begin{array}{c}\mathrm{NaCl}+\mathrm{MgSO}_{4} \\
(+)\end{array}$ & $\begin{array}{c}\text { Ratio } \\
(+/-)\end{array}$ \\
\hline $\mathrm{P}-20,000$ & $1.84^{*)}$ & 2.40 & 1.30 & 2.95 & 1.60 & 3.14 & 1.70 \\
$\mathrm{~S}-20,000$ & 1.20 & 1.20 & 1.00 & 2.56 & 2.14 & 2.33 & 1.94 \\
\hline
\end{tabular}

was examined. As shown in Table II, $\mathrm{NaCl}$ also enhanced the phosphatase activity of $\mathrm{P}-20,000$ alone. On the other hand, $\mathrm{MgSO}_{4}$ increased the enzyme activities of both P-20,000 and S-20,000, and the enhancement was more remarkable in S-20,000 than $\mathrm{P}-20,000$. In the presence of both $\mathrm{MgSO}_{4}$ and $\mathrm{NaCl}$ an additional activation was observed in the enzyme activity of P-20,000. These results suggest that the mechanism of activation of alkaline phosphatase in intestinal mucosa by $\mathrm{NaCl}$ seems to differ from that by $\mathrm{MgSO}_{4}$.

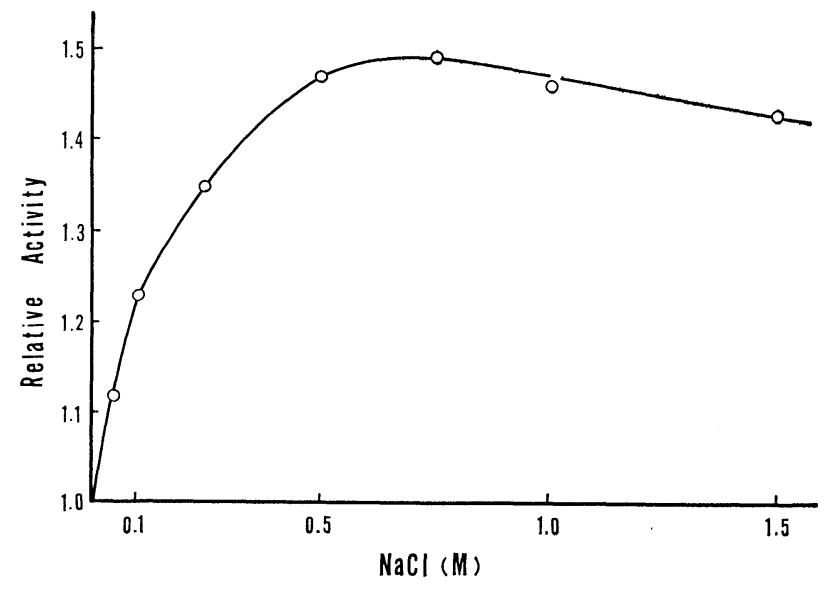

Fig. 1. Effect of various concentrations of $\mathrm{NaCl}$ on alkaline phosphatase activity.

The optimum concentration of $\mathrm{NaCl}$ in the enhancement of phosphatase activity of $\mathrm{P}-20,000$ was $500-1,000 \mathrm{mM}$ (Fig. 1). $\mathrm{KCl}$ was also effective like $\mathrm{NaCl}$. As regards the activation by $\mathrm{MgSO}_{4}$, concentration at $5-10 \mathrm{mM}$ was found to be most effective.

Effect of inhibitors. Effect of ethylenediaminetetraacetic acid (EDTA) and sodium tetraborate on the alkaline phosphatase activity of $\mathrm{P}-20,000$ fraction was examined with or without $\mathrm{NaCl}$. It was found that EDTA inhibited the enzyme activity at concentration above $0.1 \mathrm{mM}$. The rate of inhibition was significantly lower in the presence of $500 \mathrm{mM} \mathrm{NaCl}$ than that in the absence of $\mathrm{NaCl}$ (Table III). On the contrary, the inhibitory rate by $35 \mathrm{mM}$ sodium borate was 
$45 \%$ with $\mathrm{NaCl}$ and $39 \%$ without $\mathrm{NaCl}$. Ouabain (0.01-1 mM) showed no inhibitory effect on the phosphatase activity.

Table III. Inhibitory effect of ethylenediaminetetraacetate on alkaline phosphatase activity

\begin{tabular}{c|c|c|c}
\hline \multirow{2}{*}{$\begin{array}{c}\text { Concentration } \\
(\mathrm{mM})\end{array}$} & \multicolumn{2}{|c|}{ Inhibition (\%) } & $P$ \\
\cline { 2 - 3 } & $\mathrm{NaCl}(-)$ & $\mathrm{NaCl}(+)$ & \\
\hline 0.01 & 0 & 0 & \\
0.1 & $\left.39 \pm 5.1(4)^{*}\right)$ & $21 \pm 1.9(4)$ & $<0.02$ \\
1 & $58 \pm 2.0(5)$ & $26 \pm 3.2(5)$ & $<0.001$ \\
10 & 65 & 53 & \\
\hline
\end{tabular}

*) Mean \pm standard error. Numbers in parentheses indicate the number of animals.

Effect of adaptation of rainbow trout to sea water on their intestinal alkaline phosphatase activity. Morphologically two portions can be distinguished in the intestine of rainbow trout by the thickness of its wall, namely a thinner anterior and a thicker posterior half. A comparison was, therefore, made between these two portions with respect to the alkaline phosphatase. As a result, the activity of P-20,000 derived from mucosa of the anterior half of the intestine was significantly higher than that from mucosa of the posterior half, although the rate of activation by $500 \mathrm{mM} \mathrm{NaCl}$ was identical in both cases (Table IV).

Table IV. Comparison of alkaline phosphatase activity between anterior and posterior half of the intestine

\begin{tabular}{|c|c|c|c|c|}
\hline \multirow{2}{*}{ Intestine } & \multirow{2}{*}{$\begin{array}{l}\text { No. of } \\
\text { eels }\end{array}$} & \multicolumn{2}{|c|}{$\mu$ moles $p-\mathrm{NP} / \mathrm{g} / \mathrm{min}$} & \multirow{2}{*}{$\begin{array}{l}\text { Ratio } \\
(+l-)\end{array}$} \\
\hline & & $\mathrm{NaCl}(-)$ & $\mathrm{NaCl}(+)$ & \\
\hline Anterior half & 5 & $3.10 \pm 0.43 *)$ & $4.40 \pm 0.70$ & $1.41 \pm 0.16$ \\
\hline $\begin{array}{c}\text { Posterior half } \\
P\end{array}$ & 5 & $\begin{array}{l}0.90 \pm 0.18 \\
<0.01\end{array}$ & $\begin{array}{c}1.24 \pm 0.26 \\
<0.01\end{array}$ & $\begin{array}{c}1.36 \pm 0.06 \\
\mathrm{NS}\end{array}$ \\
\hline
\end{tabular}

*) Mean \pm standard error.

All experiments above described were made by using the freshwater rainbow trout as material. When the rainbow trout was adapted to sea water, the alkaline phosphatase activity of the posterior half of the intestine was found to increase significantly in the presence of $\mathrm{NaCl}(P<0.02)$. The activation ratio by $\mathrm{NaCl}$ was, however, identical in both types of trout. In the anterior half of the intestine no difference in the activity was observed between freshwater- and sea-water-adapted rainbow trout (Table V).

Effect of $\mathrm{NaCl}$ on the alkaline phosphatase activity in various tissue homogenates. Finally, the enhancing effect of $500 \mathrm{mM} \mathrm{NaCl}$ 
Table V. Effect of adaptation of rainbow trout to sea water on their intestinal alkaline phosphatase activity

\begin{tabular}{l|c|ccc|ccc}
\hline \multirow{2}{*}{$\begin{array}{c}\text { Type of } \\
\text { trout }\end{array}$} & \multirow{2}{*}{ No. } & \multicolumn{3}{|c|}{ Anterior half } & \multicolumn{3}{|c}{ Posterior half } \\
\cline { 2 - 7 } & & $\begin{array}{c}\mathrm{NaCl} \\
(-)\end{array}$ & $\begin{array}{c}\mathrm{NaCl} \\
(+)\end{array}$ & $\begin{array}{c}\text { Ratio } \\
(+/-)\end{array}$ & $\begin{array}{c}\mathrm{NaCl} \\
(-)\end{array}$ & $\begin{array}{c}\mathrm{NaCl} \\
(+)\end{array}$ & $\begin{array}{c}\text { Ratio } \\
(+/-)\end{array}$ \\
\hline $\begin{array}{l}\text { Freshwater } \\
\text { Sea-water }\end{array}$ & 6 & $\left.4.57 \pm 0.74^{*}\right)$ & $5.94 \pm 0.98$ & 1.31 & $0.94 \pm 0.23$ & $1.27 \pm 0.32$ & 1.34 \\
\hline
\end{tabular}

*) Mean \pm standard error $(\mu$ moles $p-\mathrm{NP} / \mathrm{g} / \mathrm{min})$.

on the alkaline phosphatase activity was examined using the homogenates from various tissues such as kidney liver, gills, and intestine of the rainbow trout. Although $30 \%$ activation by $\mathrm{NaCl}$ was always observed in the intestinal mucosa, no activation was found in the kidney and liver but $10 \%$ activation in the gills. On the contrary, the alkaline phosphatase activity in the homogenates of mouse intestinal mucosa, was found to be inhibited by $\mathrm{NaCl}$, i.e., $14 \%$ and $28 \%$ inhibition was observed by addition of $100 \mathrm{mM}$ and $500 \mathrm{mM} \mathrm{NaCl}$ respectively.

Discussion. It was first shown by Yamada et $a ._{.}{ }^{2)}$ that alkaline phosphatase of a halophilic bacterium is enhanced by the addition of $2 \mathrm{M} \mathrm{NaCl}$. Similar activation by $\mathrm{NaCl}$ has been also reported in the alkaline phosphatase of Escherichia coli, and in this case $\mathrm{NaCl}$ and $\mathrm{MgSO}_{4}$ are equally effective at the same ionic strength. ${ }^{3)}$

In the present study, the alkaline phosphatase in the trout intestinal mucosa was found to be enhanced in the presence of high concentrations of $\mathrm{NaCl}$. Although $\mathrm{MgSO}_{4}$ also accelerated the activity of trout enzyme, its optimum concentration was very low unlike the enzyme of $E$. coli.

It is well known that in sea water, trout ingests sea water and absorb water together with $\mathrm{NaCl}$ from the intestine to compensate for water deprivation in the body. The fact that an increase occurred in the activity of the intestinal alkaline phosphatase in response to the adaptation to sea water of the trout suggests that the enzyme may play some roles in the salt adaptation of this euryhaline teleost.

Summary. A high concentration of $\mathrm{NaCl}$ was found to enhance the alkaline phosphatase activity in the homogenates of intestinal mucosa of rainbow trout, Salmo gairdnerii. When the homogenates were fractionated, the highest activity was observed in the precipitate after centrifugation at $20,000 \times g$. The activation by $500 \mathrm{mM} \mathrm{NaCl}$ was also higher in the same fraction than in the supernatant fraction. On the other hand, $5 \mathrm{mM} \mathrm{MgSO}_{4}$ enhanced the enzyme activity more remarkable in the supernatant than the precipitate after 
$20,000 \times g$. The mucosal alkaline phosphatase activity was three times higher in the anterior half of the intestine than in the posterior. When the rainbow trout was adapted to sea water the enzyme activity in the posterior half of the intestine was found to increase markedly, although in the anterior half no such effect was observed.

Finally the helpful assistance of Misses S. Horikawa and H. Kondo is acknowledged.

\section{References}

1) Stadtman, T. C.: The Enzymes 5, 55 (1961). Ed. by Boyer, P. D., Lardy, H., and Myrbäck K. Academic Press, New York.

2) Yamada, T., Shiino, I., and Egami, F.: Proc. Japan Acad., 30, 113 (1954).

3) Plocke, D. J., and Vallee: B. L. Biochemistry, 1, 1039 (1962).

4) Lohmann, K., and Jendrássik L.: Biochem. Z., 178, 419 (1926). 